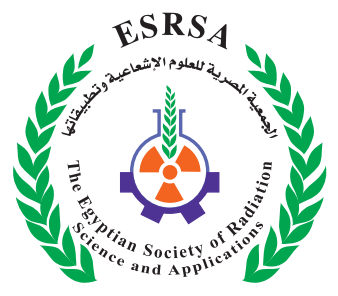

J. Nucl. Tech. Appl. Sci., Vol. 9, PP. 53 : 61 (2021)

\title{
A Rapid and Simple Method for Determination of Uranium in Gattar Area by ICP-OES
}

El-Wakil, A.F. and Mahdy, N.M.

Received: 24/05/2021

Accepted: 31/07/2021

DOI: $10.21608 /$ jntas.2021.76686.1041

E.mail:azzafw@yahoo.com
KEYWORDS

ICP-OES; Uranium,

Geological

Sample, Granite,

Determination.
ABSTRACT

This experiment was carried out to determine Uranium in a geological samples collected from Gattar area, North Eastern Desert of Egypt which examined by scanning electron microscope (EDX) to be characterized by hematization, silicification, muscovitization and fluoritization which are the most dominant alteration associated with the uranium mineralization. Inductively coupled plasma optical emission spectrometry (ICP-OES) was used for this study. Two methods of digestion of samples were used in the experiment and four emission lines were selected for uranium to choose the more sensitive one. The physical parameter conditions were adjusted by using standard solution of uranium to be $1200 \mathrm{~W}$ for RF power current, 35 psi for nebulizer gas pressure and $18 \mathrm{~L} / \mathrm{min}$ for coolant gas pressure. The interference effect of some elements was studied on the selected line and showed that, the determination of uranium by ICPOES is affected seriously by iron, aluminum, calcium, thorium and rare earth elements. The results of uranium determination at $303.199 \mathrm{~nm}$ with precipitation method were compared with the results from XRF method which shown acceptable accuracy and low time consuming other method.

1. Nuclear Materials Authority, P. O. Box 530 El Maadi, Cairo, Egypt. 


\section{.INTRODUCTION}

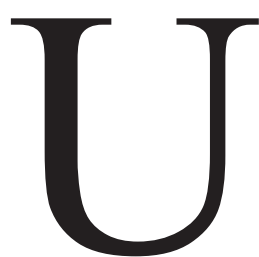

ranium occurs naturally in low concentration in rock and soil; it decays slowly by emitting $(\alpha)$ particles. Uranium and its compounds are very important especially during the processing of nuclear fuel. Therefore the development of an accurate analytical method for uranium determination is always important (Reddy et al., 2011).

Sensitive and reliable analytical method for the determination of Uranium is very important for the evaluation in geological samples. Various methods have been used for this purpose including atomic absorption spectrometry (Anirudhan et al., 2010), molecular absorption spectrometry (Ferreira et al., 2006), fluorimetry (Tarafder et al., 2002), inductively coupled plasma mass spectrometry (grinberg $\boldsymbol{e t}$ al., 2005) and X-ray fluorescence (Rathore, 2008).

Inductively coupled plasma optical emission spectrometry (ICP-OES) is widely used for the determination of elements in different materials as water, soil and geological materials (Florian et al., 1998 and Marin et al., 2008).

Table (1) : The operating conditions of ICP-OES.
The ICP-OES system may suffers from some errors originated from the measurement techniques or from different steps before the analytical procedure which must take care of it such as collecting, storage and sample preparation

The Uranium determination by ICP-OES has difficulties that limit the accuracy and precision of the obtained data. Uranium has several spectral lines in the wavelength range between $200 \mathrm{~nm}$ and $400 \mathrm{~nm}$. So, it is very important for accurate determination is the line which must be free of element interference. If the sample contains interfering elements with line - rich spectra, the detection power could be lost. The main reasons are the partial or complete between the analytic lines and the concomitants lines, a higher noise and a decrease of the signal to background ratio (Avranov et al., 2009).

\section{MATERIALS AND METHOD}

\section{Instrumentation and operating conditions}

Measurements were performed using Prism ICP high dispersion, Teledyne Leeman Labs. (U.S.A.) with an axial configuration whose operating conditions in Table (1) and JENWAY pH meter was used to determine the $\mathrm{pH}$ balance of the samples.

\begin{tabular}{|c|c|}
\hline Parameter & Plasma conditions \\
\hline RF power current & $1200 \mathrm{Watt}$ \\
\hline Coolant gas & $18 \mathrm{ml} / \mathrm{min}$ \\
\hline Nebulizer gas flow & $35 \mathrm{psi}$ \\
\hline Sample uptake rate & $1.4 \mathrm{ml} / \mathrm{min}$ \\
\hline Sample uptake time & $20 \mathrm{sec}$ \\
\hline Replicates & 3 \\
\hline PMT voltage & $800 \mathrm{~V}$ \\
\hline
\end{tabular}

\section{Reagents and Materials}

All acids were of the grade for inductively coupled plasma (Burdick\& Jackson, Germany), the standards used for calibration and overview of the physical operating parameters were ICP-AES \& ICP-MS and ICP-OES standard solutions $1000 \mathrm{ppm}$ spikes on $4 \% \mathrm{HNO}_{3}$ manufactured in Canada. High-purity water with a resistivity $>18 \mathrm{M} \Omega$ was obtained from Human lab Instrument Co. and fed with de-ionized water (Aquatron). 


\section{RESULTS AND DISCUSSION}

In this study, the lines U286.568, U302.221, U303.199 and U306.254 were chosen with the consideration of the least spectral interference with uranium. To obtain the most accurate line for the determination of uranium in some geological samples, two standard solutions of uranium with concentration $6.3 \times 10^{-5}$ and $10.5 \times 10^{-5} \mathrm{M}$ (single element) was used to test the lines and obtain the correct determination one with acceptable accuracy, table 2 showed that, the line $303.199 \mathrm{~nm}$ was relatively the most accurate line, which has a linear calibration curve $\left(\mathrm{r}^{2}=0.997\right)$ in the range from $4.2 \times 10^{-6} \mathrm{M}(1 \mathrm{ppm})$ to $42.0 \times 10^{-6}$ $\mathrm{M}(10 \mathrm{ppm})$ with detection limit up to $0.21 \times 10^{-6} \mathrm{M}$ (50 ppb). The standard solution of $10.5 \times 10^{-5} \mathrm{M}$ ura- nium was used also to evaluate the effect of some physical parameters on the accuracy of the determination using the selected line. For studying the effect of the radio frequency power, the power range between $600 \mathrm{~W}$ and $1400 \mathrm{~W}$ was studied (table $3-\mathrm{a}$ ) to obtain the optimum reading at $1200 \mathrm{~W}$. While in case of the effect of the coolant gas pressure, the studied range was between 14 and 20L/min using standard solution of uranium with conc. $10.5 \times 10^{-5} \mathrm{M}$ (table $3-b)$. For the nebulizer gas pressure which controls the sample exposure with plasma, this parameter was studied by the same standard solution of uranium in the range between 20 and 45 Psi. to give the optimum readings at 35 Psi respectively (table 3 -c).

Table (2) : The selection of the most accurate line of uranium relative to two concentrations.

\begin{tabular}{|c|c|c|c|c|c|c|}
\hline $\begin{array}{c}\text { Wave length } \\
(\mathbf{n m})\end{array}$ & $\begin{array}{c}\text { Actual conc. } \\
\text { Of Uranium } \\
(\mathbf{M})\end{array}$ & $\begin{array}{c}\text { Measured } \\
\text { conc. Of } \\
\text { Uranium }(\mathbf{M})\end{array}$ & $\begin{array}{c}\text { SD } \\
(\boldsymbol{\sigma})\end{array}$ & $\begin{array}{c}\text { RSD } \\
\mathbf{( \% )}\end{array}$ & $\begin{array}{c}\text { Accuracy } \\
(\mathbf{\%})\end{array}$ & $\begin{array}{c}\text { Uncertainty } \\
(\mathbf{u})\end{array}$ \\
\hline \multirow{2}{*}{$286.568 \mathrm{~nm}$} & $6.3 \times 10^{-5} \mathrm{M}$ & $0.5 \times 10^{-5} \mathrm{M}$ & 0.06245 & $12.49 \%$ & $7.94 \%$ & 0.0361 \\
& $10.5 \times 10^{-5} \mathrm{M}$ & $1.99 \times 10^{-5} \mathrm{M}$ & 0.09539 & $4.79 \%$ & $18.95 \%$ & 0.0551 \\
\hline \multirow{2}{*}{$302.221 \mathrm{~nm}$} & $6.3 \times 10^{-5} \mathrm{M}$ & $2.35 \times 10^{-5} \mathrm{M}$ & 0.11358 & $4.83 \%$ & $37.30 \%$ & 0.0656 \\
& $10.5 \times 10^{-5} \mathrm{M}$ & $4.32 \times 10^{-5} \mathrm{M}$ & 0.070 & $1.62 \%$ & $41.14 \%$ & 0.0404 \\
\hline \multirow{2}{*}{$303.199 \mathrm{~nm}$} & $6.3 \times 10^{-5} \mathrm{M}$ & $7.15 \times 10^{-5} \mathrm{M}$ & 0.03606 & $0.50 \%$ & $86.51 \%$ & 0.0208 \\
& $10.5 \times 10^{-5} \mathrm{M}$ & $12.71 \times 10^{-5} \mathrm{M}$ & 0.030 & $0.24 \%$ & $78.95 \%$ & 0.0173 \\
\hline \multirow{2}{*}{$306.254 \mathrm{~nm}$} & $6.3 \times 10^{-5} \mathrm{M}$ & $1.11 \times 10^{-5} \mathrm{M}$ & 0.02646 & $2.38 \%$ & $17.62 \%$ & 0.0153 \\
& $10.5 \times 10^{-5} \mathrm{M}$ & $2.14 \times 10^{-5} \mathrm{M}$ & 0.030 & $1.40 \%$ & $20.38 \%$ & 0.0173 \\
\hline
\end{tabular}

Table (3)a : The effect of RF power current on the accuracy \% of the uranium determination at wavelength $303.199 \mathrm{~nm}$.

\begin{tabular}{|c|c|c|c|c|c|}
\hline RF power current & $600 \mathrm{~W}$ & $800 \mathrm{~W}$ & $1000 \mathrm{~W}$ & $1200 \mathrm{~W}$ & $1400 \mathrm{~W}$ \\
\hline Actual U con. & $10.5 \times 10^{-5} \mathrm{M}$ & $10.5 \times 10^{-5} \mathrm{M}$ & $10.5 \times 10^{-5} \mathrm{M}$ & $10.5 \times 10^{-5} \mathrm{M}$ & $10.5 \times 10^{-5} \mathrm{M}$ \\
\hline Measured U conc. & $4.2 \times 10^{-5} \mathrm{M}$ & $5.7 \times 10^{-5} \mathrm{M}$ & $6.8 \times 10^{-5} \mathrm{M}$ & $10.0 \times 10^{-5} \mathrm{M}$ & $12.9 \times 10^{-5} \mathrm{M}$ \\
\hline SD (б) & 0.06245 & 0.08888 & 0.10066 & 0.1044 & 0.08888 \\
\hline RSD (\%) & $1.49 \%$ & $1.56 \%$ & $1.48 \%$ & $1.04 \%$ & $0.69 \%$ \\
\hline Accuracy (\%) & $40 \%$ & $54.29 \%$ & $64.76 \%$ & $95.24 \%$ & $77.14 \%$ \\
\hline Uncertainty (u) & 0.0361 & 0.0513 & 0.0581 & 0.0603 & 0.0513 \\
\hline
\end{tabular}


Table (3)b : The effect of coolant gas pressure on the accuracy \% of the uranium determination at wave length $303.199 \mathrm{~nm}$.

\begin{tabular}{|c|c|c|c|c|}
\hline Coolant gas pressure & $14 \mathrm{~L} / \mathrm{min}$. & $16 \mathrm{~L} / \mathrm{min}$. & $18 \mathrm{~L} / \mathrm{min}$. & $20 \mathrm{~L} / \mathrm{min}$. \\
\hline Actual U con. & $10.5 \times 10^{-5} \mathrm{M}$ & $10.5 \times 10^{-5} \mathrm{M}$ & $10.5 \times 10^{-5} \mathrm{M}$ & $10.5 \times 10^{-5} \mathrm{M}$ \\
\hline Measured U conc. & $5.2 \times 10^{-5} \mathrm{M}$ & $7.4 \times 10^{-5} \mathrm{M}$ & $10.1 \times 10^{-5} \mathrm{M}$ & $12.2 \times 10^{-5} \mathrm{M}$ \\
\hline SD (б) & 0.02646 & 0.03605 & 0.30 & 0.06557 \\
\hline RSD (\%) & $0.51 \%$ & $0.49 \%$ & $0.30 \%$ & $0.54 \%$ \\
\hline Accuracy (\%) & $49.52 \%$ & $70.48 \%$ & $96.19 \%$ & $83.81 \%$ \\
\hline Uncertainty (u) & 0.0153 & 0.0208 & 0.1732 & 0.0379 \\
\hline
\end{tabular}

Table (3)c : The effect of nebulizer gas pressure on the accuracy \% of the uranium determination at wave length $303.199 \mathrm{~nm}$.

\begin{tabular}{|c|c|c|c|c|c|c|}
\hline Nebulizer gas pressure & $20 \mathrm{Psi}$ & $25 \mathrm{Psi}$ & 30 Psi & 35 Psi & 40 Psi & 45 Psi \\
\hline Actual U con. & $10.5 \times 10^{-5} \mathrm{M}$ & $10.5 \times 10^{-5} \mathrm{M}$ & $10.5 \times 10^{-5} \mathrm{M}$ & $10.5 \times 10^{-5} \mathrm{M}$ & $10.5 \times 10^{-5} \mathrm{M}$ & $10.5 \times 10^{-5} \mathrm{M}$ \\
\hline Measured U conc. & $5.9 \times 10^{-5} \mathrm{M}$ & $7.3 \times 10^{-5} \mathrm{M}$ & $8.5 \times 10^{-5} \mathrm{M}$ & $10.6 \times 10^{-5} \mathrm{M}$ & $11.8 \times 10^{-5} \mathrm{M}$ & $13.7 \times 10^{-5} \mathrm{M}$ \\
\hline SD (б) & 0.0264 & 0.02646 & 0.04582 & 0.02646 & 0.02645 & 0.030 \\
\hline RSD (\%) & $0.45 \%$ & $0.36 \%$ & $0.54 \%$ & $0.25 \%$ & $0.22 \%$ & $0.22 \%$ \\
\hline Accuracy \% & $56.19 \%$ & $69.52 \%$ & $80.95 \%$ & $99.05 \%$ & $87.62 \%$ & $69.52 \%$ \\
\hline Uncertainty (u) & 0.0152 & 0.0153 & 0.0265 & 0.0153 & 0.0153 & 0.0173 \\
\hline
\end{tabular}

An important part of the detection power of ICPOES could be lost if the sample contains a major element with line-rich spectra so, the interference effect of some elements was studied on the selected line using a solution of $8.4 \times 10^{-5} \mathrm{M}$ uranium with the expected interfering elements which showed that, the determination of uranium by ICP-OES is affected seriously by iron, aluminum, calcium, thorium and rare earth elements (table 4). Accordingly, pre-concentration and separation procedure is required to overcome the interferences caused by the interfering metals which will be by precipitation in this study. The separation and determination process were applied on a granitic samples from Gattar, North Eastern Desert, Egypt.

Table (4) : The interference effect of some metals on the determination of 8.4×10-5 M standard solution uranium.

\begin{tabular}{|c|c|c|c|c|c|c|c|c|c|}
\hline \multicolumn{10}{|c|}{$8.4 \times 10^{-5} \mathrm{M}$ standard solution of $U$ at wavelength $303.199 \mathrm{~nm}$} \\
\hline \multicolumn{2}{|c|}{ (Fe) effect } & \multicolumn{2}{|c|}{ (AI) effect } & \multicolumn{2}{|c|}{ (Ca) effect } & \multicolumn{2}{|c|}{ (Th) effect } & \multicolumn{2}{|c|}{ (Total REEs)effect } \\
\hline $\begin{array}{l}\text { Added } \\
(\mathrm{Fe}) \\
\text { conc. } \\
\times 10^{-4} \mathrm{M}\end{array}$ & 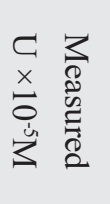 & $\begin{array}{l}\text { Added } \\
\text { (Al) } \\
\text { conc. } \\
\times 10^{-3} \mathrm{M}\end{array}$ & $\begin{array}{ll}c & 3 \\
\times & 8 \\
\stackrel{8}{0} & \vdots \\
\dot{0} & \vdots \\
\dot{山} & 0\end{array}$ & $\begin{array}{l}\text { Added } \\
(\mathrm{Ca}) \\
\text { conc. } \\
\times 10^{-4} \mathrm{M}\end{array}$ & 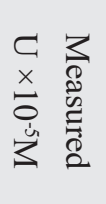 & $\begin{array}{l}\text { Added } \\
(\mathrm{Th}) \\
\text { conc. } \\
\times 10^{-5} \mathrm{M}\end{array}$ & $\begin{array}{ll}c & 3 \\
x & 0 \\
0 & 0 \\
0 & \vdots \\
\dot{u} & 0 \\
& 0\end{array}$ & $\begin{array}{c}\text { Added } \\
\text { (REEs) } \\
\text { conc. } \\
\times 10^{-6} \mathrm{M}\end{array}$ & 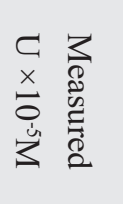 \\
\hline 17.54 & 33.7 & 3.7 & 16.8 & 12.5 & 14.1 & 4.3 & 7.6 & 2.28 & 8.07 \\
\hline 35.09 & 40.9 & 7.4 & 30.4 & 25.0 & 21.4 & 8.6 & 6.6 & 4.56 & 7.98 \\
\hline 52.63 & 46.6 & 11.1 & 41.9 & 37.5 & 28.5 & 12.9 & 5.4 & 6.84 & 7.81 \\
\hline 70.18 & 56.6 & 14.8 & 68.0 & 50.0 & 34.2 & 17.2 & 4.4 & 9.11 & 7.61 \\
\hline 87.72 & 109.7 & 18.5 & 87.9 & 62.5 & 40.3 & 21.6 & 4.1 & 11.39 & 7.27 \\
\hline
\end{tabular}




\section{Geological Setting and Sample Description}

Gattar batholith outcrops over an area of ca. $450 \mathrm{~km}^{2}$ in the north Eastern Desert of Egypt. Gattar batholith defines roughly elongated and elliptical shape, and extends N-S for about $33 \mathrm{Km}$ and E-W for about $20 \mathrm{Km}$ (Figure 1). It is composed of mountainous terrains with higher topographic elevations if compared to the surroundings (G. Gattar, G. Um Dissi, G. Khela, G. Abu El Hassan, G. Abu El Hassan El Ahmar, G. Um Samyuki and G. Ain Ruyashed). Along W. El Ghoza, the batholith is clearly classified into different parts (Red and Pink granite). The country rocks (Figure 1) include huge bodies of metavolcanics, arc granitoids and Hammamat sedimentary rocks (molasse-type sediments).

The uranium mineralization occurs at the northern part of the batholith at its periphery with Hammamat sedimentary rocks (Figure 1). The uranium mineralization is hosted by Gattar red granite (alkalifeldspar granite) within altered fractured and sheared zones of the granite. In other terms, the uranium mineralization is structurally controlled (the fractures, joints and sheared zones represent structural traps of this mineralization). The ore deposits are associated with the conjugated fault system (Figures 1 and 2) (Mahdy, 2011; Mahdy et al., 2014 and Mahdy et al., 2015). The uranium mineralization is hydrothermally produced and associated with alterations of the host Gattar granite. The size of hydrothermal minerals increases with degree of alteration, and the alteration displays vast zonings close to the $U$ mineralization, mainly characterized by hematitization, silicification, muscovitization and fluoritization but the hematitization, silicification, and fluoritization are the most dominant alteration associated with the U mineralization (Figure 2).

The iron oxides occur as fillings (cavities and vugs), and coatings within the granite along the fractures and joints (Figures $1 \mathrm{~b}$ and $2 \mathrm{a}$ ). Within highgrade $U$ deposits, the degree of hematitization increases. The hematitized granites are hard and their colors become reddish brown to brown due to the impregnation of all forming minerals with hematite and loss of their plagioclase and perthite contents.

Silicification is a common alteration feature within the U mineralized zones. It is commonly represented by white and smoky quartz veinlets filling joints, fractures and shear zones that are dominant through the NNE-SSW, NW-SE and E-W trends (Figure 1a, c). Quartz occurs as primary crystals of medium size and as secondary fine crystals filling the interstices between the minerals. It shows five forms (Mahdy, 2011):

1. Crushed grains occupying the inter-granular spaces between the other essential minerals,

2. Inclusions of variable sizes and shapes within the other mineral phases,

3. Inclusions of fine rounded grains inside and at the edges of feldspar crystals forming poiklitic texture, i.e., silicification processes,

4. Overgrowth as result of dissolution of quartz, and

5. Relics of magmatic quartz surrounded by automorphic euhedral quartz and this type rise from the recurrent dissolution-recrystallization of quartz.

Fluoritization is an important alteration feature associated with the $\mathrm{U}$ mineralization (Figures $1 \mathrm{~b}$ and 2b). Fluorite occurs as disseminations and / or forming thin veinlets and encrustations filling some mineralized fissure and fractures. Fluorite is mostly characterized by its dark violet color as result of exogenic of uranium breakdown and evolution of hydrothermal solutions (Figure 1c) (Mahdy et al., 2014 and Mahdy et al., 2015).

Figure (1): (a) Geological map of the Gattar batholith showing the structure framework affected the area, rock units, and locations of U-Mo mineralized zones of Gattar granite as occurred at the north- 
ern part of the batholith and close to Hammamat sedimentary rocks after Mahdy et al., (2015). Field photographs (b and c) showing that the yellow visible secondary uranium is associated with intensive hematitization and silicification (b). The dark violet fluorite and quartz veins are mainly associated with the uranium deposits in the Gattar granite (c).

Figure (2): Backscattered electron (BSE) images
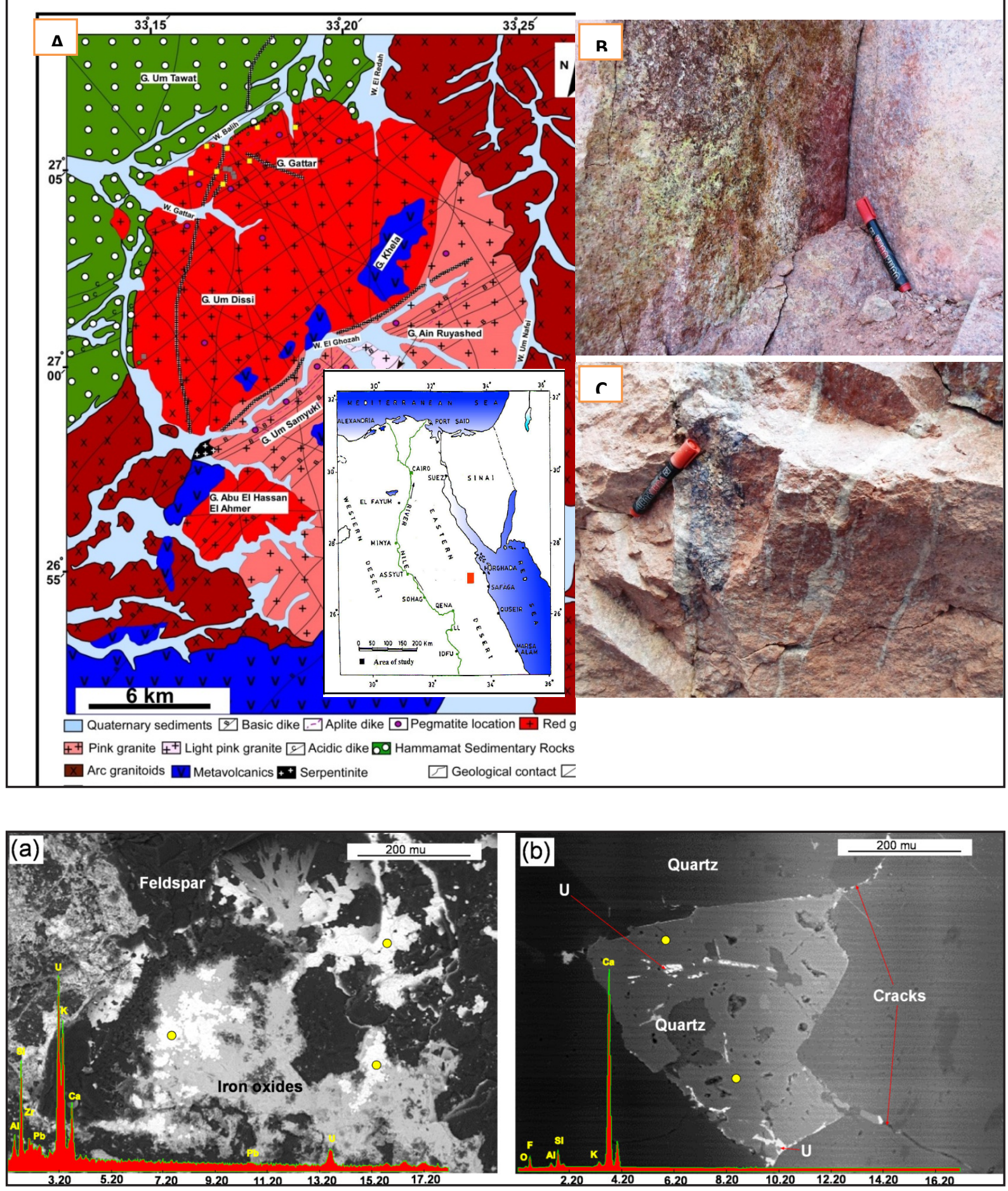
and scanning electron microscope (EDX) spectrums showing that the uranium mineralization of Gattar granite is intimately associated with iron oxides, and EDX pattern exhibiting uranophane or Betauranophane phases (illuminated bright colors) as the main uranium phases of uranium deposits in Gattar granite (a). The fluorite mineral (identified by EDX) encloses the uranium minerals as inclusions and is associated with quartz; the cracks in quartz indicate that the fluorite and uranium may be formed as postmagmatic phases after fracturing of the Gattar granite (b). Note: yellow spots refer to the spot analyses measured by scanning electron microscope.

\section{Separation and Determination}

The granitic samples were digested by two methods:

1- Excess HF with heating till dryness, cooling and adding HF (1:1), filter and to measure $U$ in the filtrate (solution 1)

2- $10 \mathrm{ml}$ of $40 \% \mathrm{HF}, 5 \mathrm{ml}$ of $68 \% \mathrm{HNO}_{3}$ and $5 \mathrm{ml}$ of $20 \% \mathrm{HClO}_{4}$ till complete drying and dissolves in $15 \mathrm{ml}$ of $20 \% \mathrm{HCl}$. (solution 2)

Few drops of concentrated nitric acid (68\%) were added to solution (2) and then boiled to convert iron (II) to iron (III).

$3 \mathrm{Fe}^{2+}+\mathrm{NO}_{3}^{-}+4 \mathrm{H}^{+}=3 \mathrm{Fe}^{3+}+\mathrm{NO}+2 \mathrm{H}_{2} \mathrm{O}$

$0.2 \mathrm{~g}$ of ammonium chloride was added and ammonium hydroxide solution was used to precipitate mainly iron and aluminium $\left(\mathrm{M}^{3+}\right)$ as hydroxides at $\mathrm{pH}$ 9. By filtration and washing the precipitate with $1 \%$ ammonium chloride solution, the main interfering elements were separated from uranium. The precipitate was dried at $60^{\circ} \mathrm{c}$ for 2 hours and scanned by scanning electron microscope (Nuclear Materials Authority, Egypt) (Figures 3,4) which showed the one sample before and after separation.

The filtrates of solution (1) and the filtrate of solution (2) after precipitation were measured by ICP-OES at the line $303.199 \mathrm{~nm}$ and the obtained re- sults compared with the results of the same samples measured at XRF technique (Nuclear Materials Authority, Egypt) which showed that, the determination after precipitation (2) is the closest result and has acceptable accuracy $\%$ comparing with other technique (table 5).On the other hand the studied method was applicated on two international standard references OKA-2 and BL-4a to validate the method (table 6).

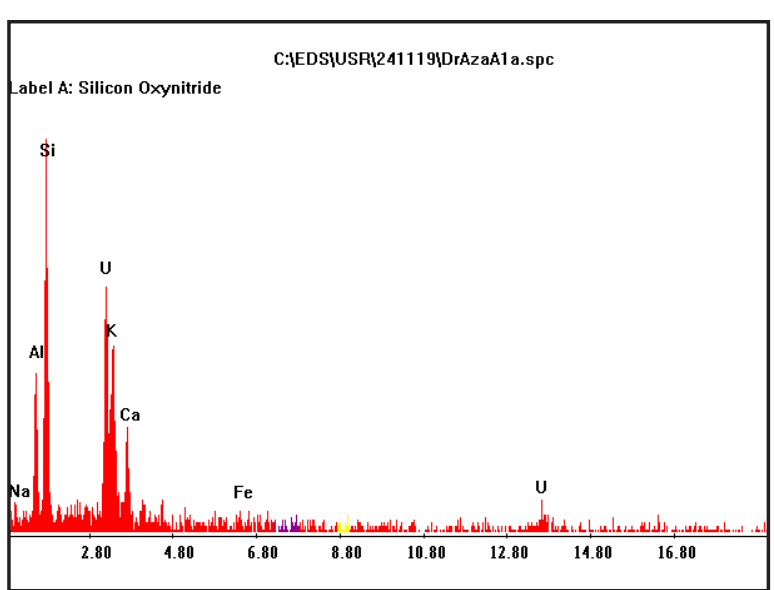

Fig. (3): The scan of the original sample which shows the existence of uranium with iron, aluminium, alkali metals and silicon.

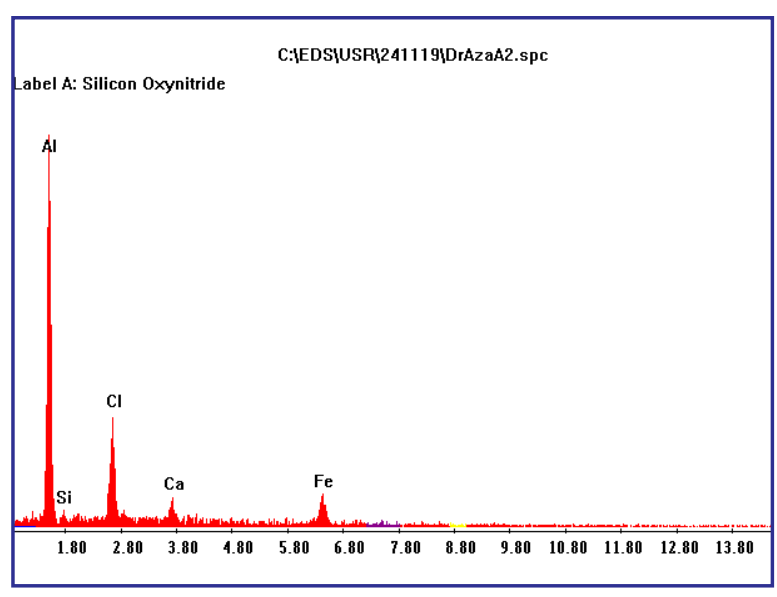

Fig. (4): The scan of the precipitate which shows the separation of uranium. 
Table (5) : Comparison between the measured uranium concentrations in granitic rock samples using ICP$O E S$ and $X R F$.

\begin{tabular}{|c|c|c|c|c|c|c|c|c|}
\hline \multirow{3}{*}{$\begin{array}{c}\text { Expected } \\
\text { conc. by } \\
\text { XRF } \\
\times 10^{-4} \mathrm{M}\end{array}$} & \multicolumn{8}{|c|}{ Measured conc. By ICP-OES } \\
\hline & \multicolumn{4}{|c|}{ By precipitation } & \multicolumn{4}{|c|}{ By excess $\mathrm{HF}$} \\
\hline & $\begin{array}{c}\text { Conc. } \times 10^{4} \\
M\end{array}$ & $\begin{array}{c}\text { RSD } \\
\%\end{array}$ & Accuracy\% & Uncertainty & $\begin{array}{c}\text { Conc. } \times 10^{4} \\
M\end{array}$ & RSD $\%$ & Accuracy\% & Uncertainty \\
\hline 45.59 & 42.35 & $0.10 \%$ & $92.893 \%$ & 0.0253 & 14.55 & $0.24 \%$ & $31.915 \%$ & 0.020 \\
\hline 46.05 & 43.07 & $0.10 \%$ & $93.529 \%$ & 0.030 & 22.13 & $0.12 \%$ & $48.056 \%$ & 0.020 \\
\hline 92.24 & 90.00 & $0.14 \%$ & $97.572 \%$ & 0.080 & 43.84 & $0.06 \%$ & $47.528 \%$ & 0.020 \\
\hline
\end{tabular}

Table (6) : Comparison of uranium concentration in international standard references and the present studied method.

\begin{tabular}{|c|c|c|c|c|c|c|}
\hline $\begin{array}{c}\text { International } \\
\text { Standard References }\end{array}$ & $\begin{array}{c}\text { Certified } \\
\text { value (M) }\end{array}$ & $\begin{array}{c}\text { Measured U } \\
\text { conc.(M) }\end{array}$ & SD ( $)$ & RSD\% & Accuracy\% & $\begin{array}{c}\text { Uncertainty } \\
\text { (u) }\end{array}$ \\
\hline OKA-2 & $91.85 \times 10^{-5} \mathrm{M}$ & $88.34 \times 10^{-5} \mathrm{M}$ & 0.02000 & $0.02 \%$ & $96.1786 \%$ & 0.0200 \\
\hline BL-4a* $^{*}$ & $52.24 \times 10^{-4} \mathrm{M}$ & $50.87 \times 10^{-4} \mathrm{M}$ & 0.04359 & $0.09 \%$ & $97.3775 \%$ & 0.0522 \\
\hline
\end{tabular}

*Certified values reported by Canadian Central for Mineral and Energy Technology standard (CANMET), certifying agency.

\section{CONCLUSION}

In this study, ICP-OES (at Nuclear Materials Authority, Cairo, Egypt) was used for uranium determination without a prior separation with traditional techniques as solvent extraction or resin. In this work, the physical parameters of the instrument were optimized for the selected uranium wavelength, the interference effect from the contaminant elements were examined. The Applied geological samples from North Eastern Desert of Egypt was digested and precipitated using ammonium chloride and ammonium hydroxide to eliminate $\mathrm{M}^{3+}$ interfering elements, uranium by present study was measured and compared with the result obtained from XRF technique, this method use cheap and available chemicals and not consume time.

\section{REFERENCES}

- $\quad$ Anirudhan, T.S. and S.S. Sreekumari, S.S. (2010): Synthesis and characterization of a functionalized graft copolymer of densified cellulose for the extraction of uranium (VI) from aqueous solutions. Colloids. Surf. A Physicochem. Eng. Asp., 361(1-3): 180.
- Avranov, M.; Cobos, J.; Popa, K. and Rondinella, V.V. (2009): Determination of REE, U, TH, Ba and Zr in simulated hydrogeological leachates by ICP-AES after matrix solvent extraction. J. Rare Earths., 27(1): 123.

- Ferreira, H.S.; Benzerra, M.D. and Ferreira, S.L.C. (2006): A pre-concentration procedure using cloud point extraction for the determination of uranium in natural water. Microchem. Acta., 154 (1-2): 163.

- $\quad$ Florian, D.; Barnes, R.M. and knapp, G. (1998): Comparison of microwave assisted acid leaching techniques for the determination of heavy metals in sediments, soils and sludges. J. Anal. Chem., 362(78): 558

- Grinberg, P.; Willie, S. and Sturgeon, R.E. (2005): Determination of $\mathrm{U}$, Th and Pu in natural waters. Biological materials and clinical samples by ETV-ICPMS. J. Anal. At. Spectrom., 20: 717.

- Mahdy, N.M. (2011): Mineralogical Studies and Mineral Chemistry of Some Radioactive Mineralizations in Gabal Gattar Area, Northern Eastern Desert, Egypt. MSc thesis. Ain Shams University. 
- Mahdy, N.M.; Shalaby, M.H.; Helmy, H.M.; Osman, A.F.; El Sawey, E.H. and Abu Zeid, E.K. (2014): Trace and REE element geochemistry of fluorite and its relation to uranium mineralizations, Gabal Gattar Area, Northern Eastern Desert, Egypt. Arab. J. Geosci., 7: 2537-.

- Mahdy, N.M.; El Kalioubi, B.A.; WohlgemuthUeberwasser C.C.; Shalaby, M.H. and El-Afandy, A.H. (2015): Petrogenesis of U- and Mo-bearing A2-type granite of the Gattar batholith in the Arabian Nubian Shield, Northeastern Desert, Egypt: Evidence for the favorability of host rocks for the origin of associated ore deposits. Ore Geology Reviews, 71: 57.

- Marin, B.; Chopin, E.I.B.; Jupinet, B. and Gauthier, D. (2008): Comparison of microwave assisted digestion procedures for total trace elements content determination in calcareous soils. Talanta., 77(1): 282.

- Rathore, D.P.S. (2008): Advances in technologies for the measurement of uranium in diverse matrices. Talanta., 77(1): 9.

- Reddy, G.C.; Devanna, N. and Chandrasekhar, K.B. (2011): Derivative spectrophotometric determination of uranium (VI) using diacetylmonoxime isonicotinoyl hydrazone (DMIH). Orbital Elec. J. Chem., Campo Grande, 3(1): 24.

- Tarafder, P.K.; Murugan, P.; Kunkal, L. and Rathore, D.P.S. (2002): Extraction of uranium with 2, 3- Dihydroxynaphthalene and Cetyltrimethyl ammonium bromide and its fluorimetric determination in silicate rocks. J. Radio Anal. Nucl. Chem., 253(1): 135. 